\title{
EFFECTS OF TRUST FUND MODEL CREDIT INTERVENTION ON WELFARE OF FARMERS' HOUSEHOLDS IN OYO STATE
}

\author{
Olajide B. R. and Aderolu M. A. \\ Department of Agricultural Extension and Rural Development, University of Ibadan, University \\ of Ibadan, Nigeria \\ Corresponding Address: r.olajide@gmail.com
}

\section{ABSTRACT}

Over the years, successive governments in Nigeria prioritized agricultural sector in credit policies by establishing numerous agricultural credit programmes including Trust Fund Model (TFM). Several years on, TFM production cycles have been completed and its benefits on welfare of farmers is expected to be obvious. This study therefore investigated the effects of TFM on farmers' households' welfare in Oyo state. Simple random sampling was used to sample $40 \%$ of the beneficiaries resulting in selection of 134 beneficiaries. Using interview schedule, data was collected on beneficiaries' socioeconomic characteristics, level of awareness of the TFM components, constraints in accessing TFM funds and beneficiaries' households' welfare status. Data were analysed using descriptive (frequency, percentages and mean) and inferential (Chi square and PPMC) statistics at $p=0.05$. Results reveal that beneficiaries were aged $53 \pm 11.0$ years, mostly male (85.2\%), married (95.1\%) and with household size of $6 \pm 3.0$ persons. Amount of TFM funds received by beneficiaries was A295,655 $\pm 154,149$. Less than half (41.8\%) of the respondents were highly aware of the components of TFM and were severely constrained by delay in processing of Interest Draw Back (0.74 \pm 0.88$)$ and in release of disbursed funds (0.71 \pm 0.77$)$. Per Capita Expenditures (PCE) of $\mathrm{A504}, 816 \pm 420,330.00 \mathrm{k}$ suggest that $63.9 \%$ of the respondents belonged to core poor category. It is concluded that the TFM had not impacted positively on the beneficiaries. It is therefore recommended that the administrative bottlenecks associated with fund release and processing of interest drawback be addressed. Also, amount loanable should be increased, while condition of collateral counterpart funding be relaxed.

Keywords: Agricultural credit, Per capital expenditure, Core poor, Household welfare 


\section{INTRODUCTION}

The importance of agriculture credit in Nigeria cannot be over emphasized as the whole nation depends one way or the other on agriculture. Over $75 \%$ of the total food requirement of the nation is produced by small scale peasant farmers as farming activities are undertaken at the subsistence level (Rahji and Adeoti, 2010). These farmers are consistently faced with the constraints such as lack of adequate capital (CBN, 2003), limited access to credit facilities (Odoemenem and Obinne, 2010) and inadequate funding amongst other constraints. Agricultural credit encompasses all loans and advances granted to borrowers to finance and service production activities relating to agriculture, fisheries, and forestry and also for processing, marketing, storage and distribution of products resulting from these activities (CBN, 2001). Globally, agricultural credit has a role in increasing farmers' income and welfare through increase in production especially in developing countries. The purpose for extending production credit and capital support is basically to increase agricultural production. Agricultural credit is allocated for production activities, such as purchasing inputs (seed, fertilizers, pesticides and other chemicals), paying labour wage, renting tractors, purchasing capital and other materials (Nuryartono, Manfred, and Stefan, 2005; Adebayo and Adeola 2008; Nwaru, Ubon, Essien, and Onuoha, 2011; Saleem, 2011; Muayila, 2012).

Indeed, agricultural credit as a catalyst which drives the machinery of agricultural production and its access to credit is crucial to small scale farmers' operations (investopedia. 2012). It plays a fundamental role in determining access to the needed inputs that facilitate farming and other extensive agricultural practices which ultimately transforms into increased output and direct effect on the income of farmers which lead to better welfare of farmers (Haggblade, Hazell and Reardon, 2005).

The significance of mechanized and improved farming activities in enhancing food sufficiency for the teeming population, stimulating improvement in the field of agriculture, reducing the populace' excessive dependent on crude oil as well as transforming the nation's economy, stimulated successive governments over the years to prioritize the sector in its expenditure policies, establishing numerous agricultural credit institutions that could facilitate the flow of credit to farmers. Government also appealed to the financial institutions to devote a certain percentage of their loan-able funds to farmers while ensuring a favourable long tenure and single digit lending rate for agricultural related 
enterprises. Some of such credit schemes launched by the Federal Government of Nigeria include; Agricultural Credit Guarantee Scheme (ACGSF), Agricultural Credit Support Scheme (ACSS) and Agriculture Credit Scheme among others. The Agricultural Credit Guarantee Scheme Fund (ACGSF) started operations in April 1978 and since its inception has adopted various models to ensure the sustainable operations of its programme which includes the Self-Help Group Linkage Banking, Interest Draw Back, Refinancing and Rediscounting Facility and recently the Trust Fund Model.

The Trust Fund Model (TFM) is a framework under the Agricultural Credit Guarantee Scheme Fund (ACGSF) whereby States/Local Government, oil companies, and NonGovernmental Organizations (NGOs) place funds in trust with lending banks to augment the small group-savings of the farmers as security for agricultural loans. The Trust Fund secure 25 percent or more of the intended loans of the prospective borrowers, the farmers' savings secure another 25 percent while the Agricultural Credit Guarantee Scheme Fund guarantees 75 percent of the remaining 50 percent, thereby leaving the lending bank with a risk exposure of only 12.5 percent. The main objectives of the TFM model were to assist farmers access loans, create a good credit history, induce savings culture, help in creating enterprise and also incentive based if repayment of facility is promptly done within the agreed period. This arrangement was intended to help in ameliorating the problem of collateral requirements by commercial banks.

The various funding methods and options from both formal and informal sectors of agricultural financing have not been able to make any significant improvement on the productivity level of food crops and food security (Rahji and Adeoti, 2009). Instead, it has confined the average rural farmers to vicious cycle of poverty. In order to salvage this and help achieve increased production and improve the quality of life of the rural farmers, several credit models were introduced by the CBN in conjunction with the federal government, a part of which is the Trust Fund Model (TFM). The TFM programme from 2009 till date has been a scheme ran by commercial banks in conjunction with states government, oil companies and various NGOs. Several years on, TFM production cycles have been completed and the immense benefit of TFM on welfare of farmers is expected to be obvious, yet, no empirical findings has established the effect of this intervention on the welfare of beneficiaries. It is in the light of this that this study investigated the effect of TFM on welfare of farmers' households in Oyo state with the following specific objectives: 
1. To describe the socioeconomic characteristics of TFM credit beneficiaries in Oyo state;

2. To ascertain the level of awareness of the scheme's components by the beneficiaries;

3. To identify the constraints faced by the beneficiaries in accessing TFM facilities; and

4. To assess the household welfare status of the beneficiaries of TFM intervention.

\section{METHODOLOGY}

The study was carried out in Oyo State of Nigeria. Geographically, Oyo State lies between latitude $702^{1}$ and $901^{1}$ North and longitude $204^{1}$ and $403^{1}$ East. Farming and trading are the principal occupation of inhabitants of the state and it has a population of $5,591,589$ people (National Population Census, 2006). The population of study for this research work comprised all the beneficiaries of TFM scheme in the state.

\section{Sampling procedure and sample size}

Simple random sampling technique was used to select the respondents for the study. A list of beneficiaries of TFM was obtained from the Union Bank of Nigeria and Integrated Microfinance Bank, being the two banks that anchor the scheme as at present. The former has 183, while the latter has 153 beneficiaries. With the list of the beneficiaries, simple random sampling technique was used to select $40 \%$ from each of the banks, making 73 and 61 beneficiaries selected from Union Bank of Nigeria and Integrated Microfinance Bank, respectively. In all, a total of 134 beneficiaries were interviewed for the study.

\section{Measurement of beneficiaries' household welfare status}

Household welfare status is the dependent variable for this study and was premised on the assumption that TFM beneficiaries on accessing the TFM intervention invest on their enterprise thereby raising their productivity through financial incentives of the credit model. This was further assumed to enhance productivity resulting in more income and better purchasing power for the beneficiaries and consequently enhanced their ability to afford basic life necessities as encapsulated in the components of household welfare status.

The household welfare status was derived by asking the respondents to state the actual amount they spend on household basic items (such as food purchases, school fees, 
accommodation, utility bills, health etc.) on weekly, monthly and yearly basis depending on the expenditure item. Per capita household expenditure was derived and the welfare categories were determined using NBS (2005) method. The categories were drawn from the mean Per Capita Expenditures (PCE) using the following criteria:

Between the least value and $1 / 3$ of mean PCE = Core poor

Between $1 / 3$ and $2 / 3$ of mean PCE = Moderately poor

$2 / 3$ and highest value of mean PCE $=$ Non-poor

\section{Data analysis}

Data collected were analysed with the aid of descriptive (frequencies, percentage distribution and mean) and inferential statistics such as Chi- square and Pearson product moment correlation.

\section{RESULTS AND DISCUSSION}

\section{Respondents' socioeconomic characteristics}

The age distribution of the respondents in Table 1 shows that it ranged between 33 to 74 years with the mean age of $53 \pm 11.0$ years. About two-third (74.6\%) of the respondents were above 43 years of age, while only $25.4 \%$ were within the age of 33 to 43 years. This implies that all the respondents were adult (above 30 years) and are expected to be able to manage and be accountable for fund. This corroborates with the findings of Ologbon, Ambali and Omotuyole (2012) that older farmers had higher resource use efficiency among small scale farmers. The results in Table 1 futher reveal that majority (85.2\%) of the respondents were male. This implies that more males than females benefited from TFM and perhaps more male than female could bear risks associated with obtaining loan. It could also be as a result of the fact that in traditional African societies, male are expected to bear most financial obligations of the households and will therefore strive to meet these obligations. More importantly, most resources that could serve as collateral for obtaining loan reside with men. This is in tandem with the position of Olajide (2011) and Olajide, Raheem and Oyedele (2014) who assert that male dominate beneficiaries' groups in most development interventions including credit access. Results in Table 1 also show that $95.1 \%$ of the respondents were married and $3.3 \%$ were widowed. This implies that most of the beneficiaries are married. This is likely due to their age as age is an important consideration for marriage in several cultures in Nigeria (Ekong, 2010). Household size ranged between 1 to 15 with a mean of $6 \pm 3.0$ persons (Table 1). Household size of 4-6 persons constituted the highest percentage (54.9\%). This is similar to the findings of Lawal, Omonona, Oluwatayo and 
Salman (2016) that the mean household size of farmers was 6 persons as household size is influenced by the need for manual labour especially among cash crop farmers. Educational level of respondents as shown in Table 1 reveals that about $60.0 \%$ of the respondents had tertiary education, while only $3.3 \%$ had no formal education. This implies that majority of the respondents are likely able to understand basic terms and condition of TFM in the simplest language that it might have been explained to them. This contrasts with the submission of Adebayo and Adekunle (2016) that portrays that most farmers are not educated, perhaps due to the category of farmers investigated in their study. Results in Table 1 reveal that the mean income of respondents was $\$ 53,807 \pm 50,332$. A higher percent $(62.3 \%)$ of respondents earned less than $\$ 50,000$ monthly, less than $30.0 \%$ earned within $\$ 50,000$ to $\$ 100,000$ monthly while only $9.8 \%$ of the respondents earned above $\$ 100,000$ monthly. Most $(68.0 \%)$ of respondents owned the land they use for their agricultural enterprises, while rented and leased land among TFM beneficiaries were $17.2 \%$ and $14.8 \%$, respectively. This implies that most of the TFM beneficiaries are private owners of their farmland. This could have played a significant collateral boast for securing the loans with the various banks they were engaged with. The amount of TFM fund disbursed to farmers depends on the counterpart fund the farmer is able to make available. Results in Table 1 show that amount given ranged from $\$ 40,000$ to $\$ 500,000$ with the mean of $\mathrm{A} 295,655 \pm 154,149$. Respondents who received above $\mathrm{A} 200,000$ were $56.6 \%$ while only $43.4 \%$ received less than $N 200,000$. This suggests that the amount given as credit by TFM could not have bailed farmers from peasantry. Though, the amount is a function of what the farmers could afford for counterpart funding, it tells a lot about the non-committal stance of most government interventions that often orchestrate its readiness to diversify the economy. It is an established fact that credit is an important instrument that enables farmers to acquire commands over the use of working and fixed capitals and consumption of goods (Siddiqi et al, 2004). Credit essentially plays an important role in increasing agricultural productivity. Therefore, the amount available and condition attached to TFM are clear indications of paying lip service to farmers' bail out from credit crunch. 
Table 1 Socio- economic characteristics of TFM beneficiaries

\begin{tabular}{|c|c|c|c|c|}
\hline Variable & & Frequency & Percentage (\%) & Mean \\
\hline \multirow{4}{*}{ Age (years) } & $33-43$ & 31 & 25.4 & $53 \pm 11$ \\
\hline & $44-54$ & 37 & 30.3 & \\
\hline & $55-65$ & 42 & 34.4 & \\
\hline & $66-74$ & 12 & 9.8 & \\
\hline \multirow[t]{2}{*}{ Sex } & Male & 104 & 85.2 & \\
\hline & Female & 18 & 14.8 & \\
\hline \multirow[t]{3}{*}{ Marital status } & Single & 4 & 3.3 & \\
\hline & Married & 116 & 95.1 & \\
\hline & Widowed & 2 & 1.6 & \\
\hline \multirow[t]{4}{*}{ Household size } & $1-3$ persons & 25 & 20.5 & $6 \pm 3$ \\
\hline & 4-6 persons & 67 & 54.9 & \\
\hline & 7-9 persons & 8 & 6.6 & \\
\hline & $\begin{array}{l}10 \text { persons and } \\
\text { above }\end{array}$ & 22 & 18 & \\
\hline \multirow[t]{6}{*}{ Education } & $\begin{array}{ll}\text { No } & \text { formal } \\
\text { education } & \end{array}$ & 4 & 3.3 & \\
\hline & Primary education & 16 & 13.1 & \\
\hline & $\begin{array}{l}\text { Secondary } \\
\text { education }\end{array}$ & 29 & 23.8 & \\
\hline & OND/NCE & 27 & 22.1 & \\
\hline & HND/B.Sc. & 38 & 31.1 & \\
\hline & Post graduate & 8 & 6.6 & \\
\hline \multirow[t]{4}{*}{ Monthly income (N) } & Less than 50,000 & 76 & 62.3 & $\$ 53,807 \pm 50,332$ \\
\hline & $50,000-100,000$ & 34 & 27.9 & \\
\hline & $101,000-150,000$ & 6 & 4.9 & \\
\hline & Above 150,000 & 6 & 4.9 & \\
\hline \multirow[t]{3}{*}{ Land tenure } & Self-owned & 83 & 68 & \\
\hline & Rented & 21 & 17.2 & \\
\hline & Leased & 18 & 14.8 & \\
\hline \multirow{3}{*}{$\begin{array}{l}\text { Amount received } \\
\text { from TFM ( } \mathbb{N})\end{array}$} & $40,000-200,000$ & 53 & 43.4 & \\
\hline & $201,000-350,000$ & 25 & 20.5 & $295,655 \pm 154,149$ \\
\hline & $351,000-500,000$ & 44 & 36.1 & \\
\hline
\end{tabular}

Source: Field Survey, 2015 


\section{Awareness of the components of the Trust Fund Model}

Results in Table 2 reveal that though less than half of the respondents (41.8\%) were highly aware of the components of TFM as compared to $52.8 \%$ that fell into to low awareness level, all the respondents $(100.0 \%)$ were aware of $25 \%$ equity contribution from farmers to be kept in a savings account with the bank, percentage of Interest Draw Back (IDB) i.e. $40 \%$ of accrued interest and inculcation of savings culture in farmers. All these three components ranked first. Also, larger proportion of respondents (86.9\% and $85.2 \%)$ were aware of the $25 \%$ equity contribution from State, local government authorities or NGO deposited with Bank and the need for farmers to be in groups to be able to benefit from TFM, respectively. This implies that respondents are well aware of the components of the Trust Fund Model. In the overall, the minimum awareness score of 5 and mean score (8.0) imply that respondents are well informed and are aware of the TFM components.

Table 2: Awareness of the components of the Trust Fund Model

\begin{tabular}{|c|c|c|c|c|c|}
\hline $\begin{array}{l}\text { S/ } \\
\text { No }\end{array}$ & Components of TFM & Yes & No & WMS & Rank \\
\hline 1 & $\begin{array}{l}\text { Twenty five percent equity contribution from farmers to be } \\
\text { kept in a savings account with the bank }\end{array}$ & 100 & 0.0 & 1.00 & 1 st \\
\hline 2 & $\begin{array}{l}\text { Twenty five percent equity contribution from State, LG or } \\
\text { NGO deposited with Bank }\end{array}$ & 86.9 & 13.1 & 0.86 & $4^{\text {th }}$ \\
\hline 3 & Guarantee Certificate to be executed by each beneficiary & 43.4 & 56.6 & 0.56 & $9^{\text {th }}$ \\
\hline 4 & The Interest Draw Back (IDB) benefits for beneficiaries & 82.8 & 17.2 & 0.82 & $7^{\text {th }}$ \\
\hline 5 & Prompt payment of facility to be able to access IDB & 81.1 & 18.9 & 0.81 & $8^{\text {th }}$ \\
\hline 6 & The need for farmers to be in groups to be able to benefit & 85.2 & 14.8 & 0.85 & $5^{\text {th }}$ \\
\hline 7 & $\begin{array}{l}\text { The minimum and maximum amount that can be accessed } \\
\text { under the scheme }\end{array}$ & 25.4 & 74.6 & 0.25 & $10^{\text {th }}$ \\
\hline 8 & Maximum tenure of the facility & 83.6 & 16.4 & 0.83 & $6^{\text {th }}$ \\
\hline 9 & Percentage of IDB i.e. $40 \%$ of accrued interest & 100 & 0.0 & 1.00 & $1^{\text {st }}$ \\
\hline \multirow[t]{3}{*}{10} & The savings culture being inculcated in farmers & 100 & 0.0 & 1.00 & $1^{\text {st }}$ \\
\hline & \multirow[t]{2}{*}{ Overall awareness level } & High & 41.8 & Mean & \\
\hline & & Low & 52.8 & 8.0 & \\
\hline
\end{tabular}




\section{Constraints to accessing TFM funds}

Results in Table 3 reveal that delay in processing of Interest Draw Back (IDB) $(0.74 \pm 0.88)$ and in release of disbursed funds $(0.71 \pm 0.77)$ and poor execution of guarantee certificate $(0.45 \pm 0.50)$ were the most severe constraints to accessing TFM fund. However, cumbersomeness associated with opening credit account and delays in farmland assessment were not considered as serious constraints by TFM beneficiaries. This appears to agree with the findings of Akinwale, Ladele and Olajide, (2016) that reported better access to agricultural support services by participating farmers compared to non-participating farmers. Therefore, it implies that while TFM administrators strived to eliminate impediment in farmland assessment and opening and documentation formalities, it is apparent that the Banks need to work on fast tracking disbursement; guarantee certificate and processing of interest draw back.

Table 3: Constraints to accessing TFM funds

\begin{tabular}{|c|c|c|c|c|c|c|c|c|}
\hline $\begin{array}{l}\text { S/ } \\
\text { No }\end{array}$ & Constraints & 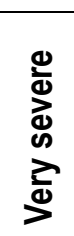 & 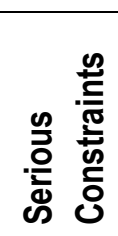 & 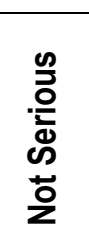 & 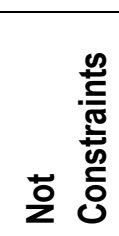 & $\sum_{3}^{\infty}$ & 只 & 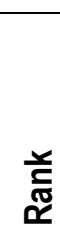 \\
\hline 1. & $\begin{array}{l}\text { Cumbersome account opening and } \\
\text { documentation process }\end{array}$ & 0.0 & 6.6 & 29.5 & 63.9 & 0.42 & 0.61 & $4^{\text {th }}$ \\
\hline 2. & Poor execution of Guarantee certificate & 0.0 & - & 45.9 & 54.1 & 0.45 & 0.50 & $3^{\text {rd }}$ \\
\hline 3. & Delay in release of disbursed funds & 1.6 & 14.8 & 36.9 & 46.7 & 0.71 & 0.77 & $2^{\text {nd }}$ \\
\hline 4. & $\begin{array}{l}\text { Delayed processing of Interest Draw } \\
\text { Back (IDB) }\end{array}$ & 8.2 & 4.9 & 40.2 & 46.7 & 0.74 & 0.88 & $1^{\text {st }}$ \\
\hline 5. & $\begin{array}{l}\text { Delayed assessment of farmland by } \\
\text { agents }\end{array}$ & 0.0 & 1.6 & 14.8 & 83.6 & 0.18 & 0.42 & $5^{\text {th }}$ \\
\hline
\end{tabular}

Source: Field Survey, 2015

WMS= Weighted Mean Scores

\section{Household welfare status of TFM beneficiaries}

Based on the mean Per Capita Expenditures (PCE) of $\$ 504,816 \pm 420,330.00 \mathrm{k}, 63.9 \%$ of the respondents belonged to the core poor category, while $23.0 \%$ and $13.1 \%$ were moderately poor and non-poor, respectively (Table 4). This implies that although the TFM was accessed by beneficiaries, it has not improved the welfare status of majority of the respondents. This 
could be attributed to the amount of credit accessible to farmers that was too small for a meaningful impact.

Table 4: Categorization of TFM beneficiaries based on their welfare status

\begin{tabular}{lllllll}
\hline Welfare status & Frequency & $\%$ & Min & Max & S D & $\begin{array}{l}\text { Mean } \\
\text { score }\end{array}$ \\
\hline Core poor & 78 & 63.9 & 38,900 & $1,657,000$ & 420,330 & 504,816 \\
Moderately poor & 28 & 23.0 & & & & \\
Non-poor & 16 & 13.1 & & & & \\
Total & 122 & 100 & & & & \\
\hline
\end{tabular}

Source: Field survey, 2015

Test of relationships and correlations between respondents' selected socioeconomic characteristics, constraints and their household welfare status

Available statistics on relationship and correlation analyses in Table 5 reveals that respondents' $\operatorname{sex}\left(x^{2}=7.841, p=0.02\right)$, educational status $\left(x^{2}=29.219, p=0.001\right)$, marital status $\left(x^{2}=15.675, p=0.003\right)$, land ownership $\left(x^{2}=11.242, p=0.022\right)$, monthly income $(r=0.312, p=0.00)$ and household size $(r=0.273, p=0.002)$ were significantly related to beneficiaries' household welfare status. This implies that a male, married, educated and landlord beneficiaries may be well placed in welfare status compared to a female, noneducated, single or divorced and tenants farmers. Also, the less the constraints faced by beneficiaries in accessing and deploying TFM facilities, the more effective they are able to utilise the facility and the better such beneficiaries are placed in the welfare cadre. Contrastingly, the import of the data available on household size can be variedly interpreted. Though, larger household size confers some advantage when labour for the farm operation is considered, it bestows corresponding responsibilities when it comes to taken care of household welfare. Therefore, while beneficiaries with larger household size may safe costs of labour, it is more predispose to incurring more expenses in household welfare spending. Inabilities to fulfil such responsibilities may plunge such households in poor and core poor categories of the welfare cadre. Lawal, Omonona, Oluwatayo and Salman, (2016) implicated related variables in their investigation of the welfare correlates among cocoa farming households in Nigeria. 
Table 5: Statistical analysis of respondent's socioeconomic characteristics of respondents and their welfare status

\begin{tabular}{lllllll}
\hline Variable & $\mathbf{N}$ & $\mathbf{x}^{2}$-value & r-value & Df & p-value & CC-value \\
\hline Sex & 122 & 7.841 & - & 1 & $0.020^{*}$ & 0.246 \\
Religion & 122 & 4.545 & - & 2 & 0.337 & 0.190 \\
Education & 122 & 29.219 & - & 5 & $0.001^{*}$ & 0.440 \\
Marital status & 122 & 15.675 & - & 3 & $0.003^{*}$ & 0.337 \\
Land ownership & 122 & 11.424 & - & 2 & $0.022^{*}$ & 0.293 \\
Income & 122 & - & 0.312 & & $0.000^{*}$ & \\
Household size & & - & 0.273 & & $0.002^{*}$ & \\
Age & 122 & - & 0.130 & & 1.154 &
\end{tabular}

*Significant@ $p \leq 0.05$

\section{CONCLUSION AND RECOMMENDATIONS}

Most beneficiaries of TFM were adult male, mostly educated with average monthly income and private owners of their farmland. Lesser beneficiaries were well aware of the components of the TFM as they were severely constrained by the delay in release of disbursed fund as well as delay in processing of interest draw back. Amount of TFM funds accessible was too small and in spite of the TFM intervention, and most of the beneficiaries' households were poor. It is recommended that the administrative bottlenecks associated with fund release and processing of interest drawback be addressed. Also, amount loanable should be increased while condition of collateral counterpart funding be relaxed.

\section{REFERENCES}

Adebayo, O. and Adeola, R.G. (2008). Sources and uses of agricultural credit by small-scale farmers in Surulere Local Government Area of Oyo State. The Anthropologist, 10 (4), 313-314

Adebayo, S. A. and Adekunle, O. A. (2016). Socio-economic status of women in group membership in selected areas of Kwara State, Nigeria. Agrosearch, Vol. 16 No 1: 59-68

Akinwale, J. A., Ladele, A. A., and Olajide, B. R. (2016). Yield Differentials Among Participating and Non-Participating Rice Farmers in Public/Private Partnership in 
Benue and Ogun State, Nigeria. Agrosearch Vol. 16 No 1: 16-25

Central Bank of Nigeria (CBN) (2003). Annual Progress Report. Central Bank of Nigeria.

Annual Report and Statement of Accounts. Abuja, Nigeria.

Central Bank of Nigeria, (2001) CBN - Annual Report. CBN, Publication.

Ekong, E. E. (2010). Rural Sociology: An Introduction and Analysis of Rural Nigeria. Dove Educational Publishers Uyo, Nigeria.3rd Edition p46

Haggblade, S., Hazell, P. and Reardon, T. (2005) The Rural Nonfarm Economy: Pathway out of Poverty or Pathway In? In: IFPRI (International Food Policy Research Institute). 2005. The future of small farms: Proceedings of a research workshop, Wye, UK, June 26-29, 2005. Washington, DC.

Investopedia (2012).Exponential Growth. Accessed on June 12, 2015 from URL http://www.investopedia.com/terms/e/exponential-growth.aspaxzz1xb0v7LRn .

Lawal, J.O., Omonona, B.T., Oluwatayo, I.B and Salman K.K. (2016). Welfare Transitions and Its Correlates Among Cocoa Farming Households in Nigeria. Agrosearch Vol. 16 No 1: 60-69

Mauyila, H.K. (2012). Assessing the impact of credit constrains on farm household economic welfare in the hinterland of Kinshasa, Democratic Republic of Congo. AJFAND online Scholarly Peer Reviewed, 12 (3)

National Population Commission (2006): Result of 2006 Population Census, NPC, Abuja, Nigeria. www.population.gov.ng

Nuryartono, N. Manfred, Z. and Stefan, S. (2005). Credit rationing of farm households and agricultural production: Empirical evidences in the rural areas of Central Sulawesi, Indonesia Tropentag Stuttgart-Hohenheim, Conference on International Agricultural Research for Development.

Nwaru. J. Ubon, C., Essien, A. and Onuoha, R.E.(2011).Determinants of informal credit demand and supply among food crop farmers in Akwa lbom State,Nigeria. Journal of Rural and Comnunity Redevelopment Vol. 6 (1) 129-139pp.

Odoemenem, I. U. and Obinne, C. P. O. (2010).Assessing the factors influencing the utilisation of improved cereal crop production technologies by small scale farmers in Nigeria. Indian journal of science and technologyVol. 2. 1ssue 2 pp.7 
Olajide B. R., Raheem R. O and Oyedele G. A (2014). Livestock Fadama Users' Access to Information on Selected Livestock Technologies in Oyo Agricultural Development Programme (ADP) Zone. African Journal of Livestock Extension Vol. 14: 46-52

Olajide, B. R. (2011). Assessment of Farmers' Access to Agricultural Information on Selected Food Crops in Iddo District of Oyo State, Nigeria. Journal of Agricultural and Food Information Vol. 12 No. 3 \& 4: 354-363

Ologbon, O.A., Ambali C. and Omotuyole I. (2012) Poultry enterprise combination among small-scale farmers inOgun State, Nigeria: a technical efficiency approach. Journal of agriculture and veterinary sciences Vol. 4

Rahji, M. A. Y. and Adeoti A. I. (2010). Determinants of Agricultural Credit Rationing by Commercial Banks in Southwestern, Nigeria. International. Research. Journal of Finance. and Economics. ISSN 1450-2887 Issue pp. 37.

Saleem, M. A. (2011). Sources and uses of agricultural credit by farmers in Deralsmail Khan (District) Khyber Pakhtonkhawa Pakistan. European Journal of. Businesss Manj.,3(3),pp.111-122.

Siddiqi M. Wasif M. and Kishwar N. B, (2004), - Institutional credit: A policy tool for enhancement of agricultural income of Pakistani International Research Journal of Arts \& Humanities Vol. 37 